\title{
GLOBALISATION AND NATURAL RESOURCES: THE EXPANSION OF THE SPANISH AGRIFOOD TRADE AND ITS IMPACT ON WATER CONSUMPTION, 1965-2010
}

\author{
Rosa Duarte ${ }^{+}$, Vicente Pinilla ${ }^{++}$and Ana Serrano ${ }^{+++}{ }^{*}$ \\ +Department of Economic Analysis, Faculty of Economics and Business Studies, Gran Vía 2, 50005 \\ Zaragoza, Spain, rduarte@unizar.es \\ ++ Department of Applied Economics and Economic History, Faculty of Economics and Business \\ Studies, Gran Vía 2, 50005 Zaragoza, Spain, vpinilla@unizar.es \\ ${ }^{++}$Department of Economy, Faculty of Economics and Business Studies, Carrer de la Universitat de \\ Girona, 10, 17071 Girona, Spain, ana.serrano@udg.edu
}

\begin{abstract}
Beginning in 1960, the Spanish agricultural sector underwent an intensive process of development, resulting in important structural changes, not only in the sector itself, but also in the relationship of the agrarian system to natural resources. These changes were closely related to the growth of per capita income, and Spain's increasing integration into international markets. In the last five decades, the volume of Spanish agricultural trade has increased strongly, with a concomitant increase in the consumption of domestic water resources, requiring the construction of water infrastructure for irrigation. This paper examines the impact on water use in Spain during a period of economic modernization and trade liberalization. More specifically, we are interested in obtaining virtual water trade flow trends and identifying the major drivers responsible for these trajectories, via a Decomposition Analysis. Our results point to a large increase in virtual water exports and imports, primarily driven by the scale effect, that is, by the growing integration into international markets. The composition effect and changes in water intensity entailed a moderation in water consumption.
\end{abstract}

Keywords: water consumption, virtual water, globalization, agrifood trade

\footnotetext{
${ }^{*}$ Corresponding author: Department of Economy, Faculty of Economics and Business Studies, Carrer de la Universitat de Girona, 10, 17071 Girona (Spain), Tel: 34972418040 Fax:34972418032 email: ana.serrano@udg.edu
} 


\section{Introduction}

The relationship between economic growth and the environment has been an issue of growing interest, particularly since the release of the Brundtland Report (UNWCED, 1987), which linked the twin factors of the environment and development, providing the impetus for the concept of sustainable development. Almost three decades later, there exists a vast literature that aims to establish the impact of long term socio-economic transition on natural resources such as timber, fossil fuels, minerals, land, water, and greenhouse gas emissions (Krausmann et al. 2008; Marull et al. 2010; Erb 2012; Iriarte-Goñi and Ayuda 2012; Rubio and Folchi 2012; Steen-Olsen et al. 2012; Fader et al. 2011; Tello and Ostos 2012; Duarte et al. 2013 and 2014a). On the whole, these studies point to the damage caused to natural environments by the long-term processes of economic growth, beginning with the Industrial Revolution. Economic growth also involves a growing integration of the international economy. The first major wave of globalization took place from the early decades of the $19^{\text {th }}$ century until 1929 , while the interwar period, especially from 1929 , can be considered a deglobalization phase, with a significant decline in the levels of economic integration (O'Rourke and Williamson 1999). Following the Second World War, a new wave of globalization occurred, and persists to this day. This second globalization has reached levels of integration that, from the 1980s, have surpassed the milestone of 1914. Thus, today's economies intensively participate in international trade, with large flows of factors and products. From an environmental perspective, it is necessary to integrate the role played by the globalization process into an analysis of the relationship between growth and natural resources (Duarte et al. 2014b; Antweiler et al. 2001).

Our study focuses on the way that long-term international economic integration has influenced water resources - the essential key to life and the successful development of societies. Water has traditionally been considered as a local resource (Katerji et al. 2008; Gleick 2010), since water used in a region was defined as the volume of surface or groundwater resources withdrawn for agricultural, industrial, or domestic purposes. However, the growing processes of internationalization involve important exchanges of agricultural commodities related to large volumes of upstream water use (Hoekstra et al. 2011). As a result, there is a need for an analysis of water resources from a global 
perspective that addresses the crucial responsibility of final consumption on water pressures. The concept of virtual water was introduced to define the volume of water required for the production of a given commodity (Allan 1993), and it is closely linked to the virtual water trade, or the volume of water embodied in products traded internationally. The virtual water content of products is classified into green water, precipitation stored in the soil as moisture, and blue water, surface or ground water (Hoekstra et al. 2011). As blue water can be reallocated to agricultural, industrial, or urban use, while green water cannot be so easily diverted (Yang et al., 2007), blue water is said to have higher opportunity costs (Hoekstra, 2010). However, green water is particularly important for agricultural and forestry products. Substituting exports of crops for 'natural vegetation' could produce greater consumption of green water and therefore less availability of blue water. This is important from the perspective of land use (Fader et al., 2011), since about $80 \%$ of global virtual water flows are related to the trade in agricultural products (UN 2009).

With a bottom-up approach (Hoekstra and Hung 2005), our study attempts to obtain and analyse long-term trends in agricultural and food virtual water trade flows. To that end, we use bilateral trade data provided by COMTRADE for the whole period analysed, as well as water intensities given by Mekonnen and Hoekstra $(2011 ; 2012)$. To link the water involved in trade with the water consumed in production, we use data on the volume of agricultural and food production in Spain (MAGRAMA 1965-2010). Once the main trajectories and compositional patterns are established, Decomposition Analysis (DA) is applied to identify and quantify the main driving forces responsible for changes in virtual water flows. This methodology, commonly used in environmental analysis, is a useful tool for the study of the factors underlying the great increase in virtual water trade flows. We focus on Spain, a semi-arid country that underwent an intensive process of economic modernization and trade liberalization from 1965 to 2010. More specifically, we want to assess the impact that this internationalization process has had on domestic water resources. This analysis is particularly important in Spain, a Mediterranean country with high spatial and temporal variability of rainfall, where imbalances between water needs and existing water resources have traditionally been managed with supply side measures 
(water channels, dumps, reservoirs, etc.), usually involving significant social, economic, and environmental impacts. Despite that virtual water trade flows in Spain have been widely studied from a short-term perspective (Aldaya et al. 2008 and 2010) and in the long term, for the seventy years before the Spanish Civil war (1936-39) (Duarte et al., 2014b), to our knowledge there are no studies that carry out a long-term analysis that coincides with the period of rapid industrialization, from 1960 on, when Spain became an advanced economy.

The Spanish case during the period studied is interesting for two other reasons. First, before the Second World War, Spain was a significant exporter of Mediterranean products, with its share in international markets being around 35\% for fruits and vegetables (Pinilla and Ayuda 2010), 30\% for olive oil (Ramón 2000) and 20\% for wine (Pinilla and Ayuda 2002). The Civil War and the early decades of the Franco dictatorship led to a substantial loss of these markets, and to an autarkic policy that isolated the country from the rest of the world. Beginning in 1959, there began a shift towards openness, culminating with entry to the European Union, in 1986. As a result, Spain has become one of the most important exporters of agrifood products in Europe, with the EU being the primary destination of Spanish agrifood products. In fact, only five countries (France, Italy, Germany, Portugal and Great Britain) together account for more than 55\% of Spanish agrifood exports. It is estimated that Spain has more than doubled its participation in agricultural world trade, which is now around 3\% (Clar et al. 2015). Second, Spain completed its industrialization process during the period analyzed, becoming a high-income country. Despite the fact that agrifood exports significantly lost ground to total exports, such exports still grew at the strongest rate in Spain's history. Thus, the Spanish case offers lessons for countries that are experiencing processes of intense economic growth and integration into international markets, as is happening in certain emerging regions.

Our findings point to a gradual growth in virtual water exports and imports, from 1965 to 2010. Although Spain is a net exporter of blue water, it appears to be a net importer of green water, meaning that, while significant pressure on regulated local resources is due to export production, Spain has avoided significant additional pressures via imports. Two groups of products, fruit and vegetables, and vegetable oils, embody most of the water in exports, while coffee, tea, cocoa and spices, textile products, and cereals are responsible for 
most of the water in imports. In summary, the great internationalization experienced in Spain throughout these years triggered a great increase in virtual water trade flows.

The rest of the paper is organized as follows. Section 2 reviews the methodology and the materials used. Section 3 shows the main findings of our study, divided into two subsections: Section 3.1 focuses on the main trends and composition of virtual water trade flows, while Section 3.2 performs a DA on virtual water exports and imports. Section 4

presents a discussion of the main results of our work, and Section 5 closes the paper with a review of our main conclusions and certain policy implications.

\section{Some stylized facts: the Spanish agrifood trade between 1965 and 2010}

The first two decades of the Franco dictatorship brought to a halt the economic transformations that the Spanish economy had experienced from the beginning of the $20^{\text {th }}$ century. The autarkic policies from 1939 to 1959 (less intense in the 1950s) led not only to the isolation of the Spanish economy, but also entailed a very slow recovery to pre-Civil War levels. Until the mid-1950s, GDP per capita and agricultural production, remained below the levels of 1935. The Stabilization Plan of 1959 supposed a turnaround in the Spanish economy, leading to internal and external liberalization, and growth was explosive from 1960. Only Japan had faster GDP growth from 1960 to 1973. Moreover, the industrialization of the Spanish economy, beginning in the $19^{\text {th }}$ century, ended during this decade, and employment in industry exceeded that of the agricultural sector for the first time.

The agricultural sector, especially after the crisis of the 1940s, resumed its modernization. Traditional agriculture gave way to an increase in production and factor productivity, achieving levels that were among the highest in Europe during the second half of the $20^{\text {th }}$ century (Martín-Retortillo and Pinilla, 2015a and 2015b).

Agrifood exports and imports also grew rapidly after 1959. Export growth was strong, with an annual average growth rate over 5.3\% between 1959 and 1986. Integration into the European Union in 1986 gave an even greater boost to commercial exchange. From 1987 to 2011, exports and imports enjoyed annual increases of 5.8\% and 4.7\%, respectively. 
Although agricultural and food products significantly lost share of total exports (falling from more than $50 \%$ of total exports in the 1950 s to less than $15 \%$ at the beginning of the $21^{\text {st }}$ century), they reached high absolute levels, showing the highest growth rates in two centuries (see Clar et al. 2015 for a more detailed study of Spain's opening to international markets). Trade in the agrifood sector grew, especially from 1986, with exports plus imports exceeding agricultural production. The composition of exports and imports also changed significantly, especially with growing exports of products derived from livestock. Whereas meat and dairy products represented less than $0.5 \%$ of exports (in current value) in 1959-1966, they accounted for more than 15\% in 2008-2011). The development of modern intensive farming was determinant. The growing imports of feed stuffs tipped the trade balance during the 1970s and '80s; cereals, oil seed cake, and other feed stuff imports were $12.5 \%$ of total agrifood imports (in current value) in 1952-1959, rising to more than $40 \%$ by 1973-1980. Exports of agrifood products, especially of processed foods, also followed an upward trend: in 1959-1966 they were only 0.7\% of total agrifood exports, but exceeded 11\% in 2008-2011 (Clar et al. 2015).

\section{Methodology and data}

\subsection{Methodological aspects}

In this study, we adopt a bottom-up perspective to quantify blue and green virtual water trade flows in agricultural and food products, based on the approach developed by Hoekstra and Hung (2005). For a country $c$ in year $t$, virtual water exports are measured in $\mathrm{m}^{3}$ and can be expressed as:

$V W X(c, t)=\sum_{p} d_{p}^{c}(c, p, t) * x_{p}^{c}(c, p, t)$

Where $x_{p}^{c}$ is the quantity (in Tons) of product $p$ exported and $d_{p}^{c}$ expresses the virtual water content in the exporting country ( $\left.\mathrm{m}^{3} / \mathrm{Ton}\right)$. Depending on whether $d_{p}^{c}$ represents green or blue water, we will distinguish between green and blue virtual water flows. 
Similarly, virtual water imports for country $c$ can be calculated as the sum of the virtual water content of the imported goods $p$ coming from a different country $z$ (origin of imported products)and are measured in $\mathrm{m}^{3}$.

$V W M(c, t)=\sum_{p, z} d_{p}^{Z}(z, p, t) * m_{p}^{Z}(z, p, t)$

with $d_{p}^{z}$ being the virtual water content (m3/Tons) in country $z$ for product $p$, and $m_{p}^{z} m_{p}^{z}$ the volume of imports (Tons) of product $p$ emanating from country $z$. Thus, the virtual water trade balance $\left(\mathrm{m}^{3}\right)$ for a country is defined as:

$V W B(c, t)=V W X(c, t)-V W M(c, t)(3)$

Once virtual water flows and balances are identified, we proceed to examine the economic factors behind changes in these flows. To that end, virtual water exports and imports are expressed as a function of trade volume, product, and country composition. Moreover, in order to analytically study trends in virtual water flows,and disentangle the forces behind trends, a form of DA is applied.

Departing from (1) and (2), water exports $\left(\mathrm{m}^{3}\right)$ can be expressed, in general terms, as dependent on three kinds of factor, representative of water content per crop $\left(w_{c p t}\right)$, trade patterns $\left(\frac{e_{c p t}}{e_{c t}}\right)$, with $e_{c p t}$ being the exports of country $c$ in year $t$ for each product $p$, and scale $\left(e_{c t}\right)$, which yields:

$V W X(c, t)=\sum_{p} w_{c p t} \cdot\left(\frac{e_{c p t}}{e_{c t}}\right) e_{c t}$

This can be expressed in matrix form as:

$V W X(c, t)=\mathbf{w}_{\mathbf{c t}}^{\prime} \mathbf{f}_{\mathbf{c t}} e_{c t}$

with $\mathbf{w}_{\mathbf{c t}}^{\prime}$ being a row vector of the water necessary for the production of each product in Spain in year $\mathrm{t}$ (measured in $\mathrm{m}^{3} / \$$ ) i.e., the water intensity, with $\mathrm{f}_{\mathrm{ct}} \widehat{E_{\bar{i}}[\boldsymbol{p}, t]}$ being a vector of Spanish export product composition in period $t$, and $e_{c t}$ a scalar of the total value of Spanish exports in year $t$ (measured in constant 1985\$). 
Similarly, we express virtual water imports $\left(\mathrm{m}^{3}\right)$ as a result of four factors; water content per crop $\left(w_{c p z t}\right)$, scale of trade $\left(m_{c t}\right)$, product composition $\left(\frac{m_{c p t}}{m_{c t}}\right)$, and country composition $\left(\frac{m_{c p z t}}{m_{c p t}}\right)$.

$V W M(c, t)=\sum_{p, z} w_{c p z t} \cdot \frac{m_{c p z t}}{m_{c p t}} \cdot \frac{m_{c p t}}{m_{c t}} m_{c t}$

or, in matrix form,

$V W M(c, t)=\mathbf{w}_{\mathbf{c z t}}^{\prime} \mathbf{M}_{\mathbf{c z t}} \mathbf{b}_{\mathbf{c t}} m_{c t}$

Where $\mathbf{w}_{\mathbf{c z t}}^{\prime}$ is a row vector of adequate dimension including the virtual water content for each product in each country of origin $z$, measured in $\mathrm{m}^{3} / \$$, i.e., the water intensity. We denote $\mathbf{M}_{\mathbf{c z t}}$ a matrix of the share that each country $z$ represents in Spanish imports of each product; $\mathbf{b}_{\mathbf{c t}} \widehat{\boldsymbol{E}_{\bar{i}}[\boldsymbol{p}, \boldsymbol{t}]}$ is a vector of product composition of imports, and $m_{c t}$ is a scalar of the total value of Spanish imports (in constant 1985 dollars).

As can be seen, all physical and economic factors underlying the trade flows are time- and country-variable. In this way, we offer an interesting approximation to the effect that changes in trade relationships, such as scale of trade, product orientation, trade partners, and technological change, can have on domestic and foreign consumption of water resources over time. More specifically, to go deeper into these factors, DA has been applied to equations (6) and (7) to synthesize the factors driving virtual water trade flows. Broadly speaking, this approach attempts to separate a time trend of an aggregated variable into a group of driving forces that can act as accelerators or retardants (Dietzenbacher and Los 1998; Lenzen et al. 2001).

In general terms, considering a variable $y$ depending on $n$ explicative factors $y=f\left(x_{1}, \ldots x_{n}\right)$, additive decomposition can be obtained through its total differential.

$d y=\frac{\partial y}{\partial x_{1}} \partial x_{1}+\frac{\partial y}{\partial x_{2}} \partial x_{2}+\cdots+\frac{\partial y}{\partial x_{n}} \partial x_{n}$

On the basis of a multiplicative relationship, that is $y=x_{1} \ldots . . x_{n}$, expression (8) holds: 
$d y=\left(x_{2} x_{3} \ldots x_{n}\right) d x_{1}+\cdots+\left(x_{1} x_{2} x_{3} \ldots x_{n-1}\right) d x_{n}=\sum_{i=1}^{n}\left(\prod_{j \neq i} x_{j} d x_{i}\right)$

In a discrete schema, when we want to measure the changes in the dependent variable between two periods, $t-1$ and $t$, there are different ways to solve this expression by way of exact decompositions, which leads to the well-known problem of no uniqueness of DA solution (Dietzenbacher and Los 1998). In our case, DA is based on four factors for imports and three factors for exports; therefore, we can obtain the following 4 ! and 3 ! exact decompositions, respectively. In practice, as a commitment solution, the average of the two polar solutions can be considered a good approximation of the average of the $n$ ! solutions (Dietzenbacher and Los 1998), with this being the option followed in this paper.

Thus, the two polar decompositions of (5) can be written as follows:

$\Delta V W X(c)=\Delta \mathbf{w}_{\mathbf{c}}^{\prime} \mathbf{f}_{\mathbf{c t}-\mathbf{1}} e_{c t-1}+\mathbf{w}_{\mathbf{c t}}^{\prime} \Delta \mathbf{f}_{\mathbf{c}} e_{c t-1}+\mathbf{w}_{\mathbf{c t}}^{\prime} \mathbf{f}_{\mathbf{c t}} \Delta e_{c}=\Delta \mathbf{w}_{\mathbf{c}}^{\prime} \mathbf{f}_{\mathbf{c t}} e_{c t}+\mathbf{w}_{\mathbf{c t}-\mathbf{1}}^{\prime} \Delta \mathbf{f}_{\mathbf{c}} e_{c t}+$ $\mathbf{w}_{\mathrm{ct}-1}^{\prime} \mathbf{f}_{\mathrm{ct}-\mathbf{1}} \Delta e_{c}$

Similarly, based on (7) we get two polar decompositions:

$$
\begin{aligned}
\Delta V W M(c)= & \Delta \mathbf{w}_{\mathbf{c z}}^{\prime} \mathbf{M}_{\mathbf{c z t}-\mathbf{1}} \mathbf{b}_{\mathbf{c t}-\mathbf{1}} m_{c t-1}+\mathbf{w}_{\mathbf{c z t}}^{\prime} \Delta \mathbf{M}_{\mathbf{c z}} \mathbf{b}_{\mathbf{c t}-\mathbf{1}} m_{c t-1}+\mathbf{w}_{\mathbf{c z t}}^{\prime} \mathbf{M}_{\mathbf{c z t}} \Delta \mathbf{b}_{\mathbf{c}} m_{c t-1} \\
& +\mathbf{w}_{\mathbf{c z t}}^{\prime} \mathbf{M}_{\mathbf{c z t}} \mathbf{b}_{\mathbf{c t}} \Delta m_{c} \\
& =\Delta \mathbf{w}_{\mathbf{c z}}^{\prime} \mathbf{M}_{\mathbf{c z t}} \mathbf{b}_{\mathbf{c t}} m_{c t}+\mathbf{w}_{\mathbf{c z t}-\mathbf{1}}^{\prime} \Delta \mathbf{M}_{\mathbf{c z}} \mathbf{b}_{\mathbf{c t}} m_{c t}+\mathbf{w}_{\mathbf{c z t}-\mathbf{1}}^{\prime} \mathbf{M}_{\mathbf{c z t}-\mathbf{1}} \Delta \mathbf{b}_{\mathbf{c}} m_{c t} \\
& +\mathbf{w}_{\mathbf{c z t}-\mathbf{1}}^{\prime} \mathbf{M}_{\mathbf{c z t}-\mathbf{1}} \mathbf{b}_{\mathbf{c t}-\mathbf{1}} \Delta m_{c}
\end{aligned}
$$

Taking the averages in (10) we get:

$$
\begin{gathered}
\Delta V W X(c)=\frac{\Delta \mathbf{w}_{\mathbf{c}}^{\prime} \mathbf{f}_{\mathbf{c t}-\mathbf{1}} e_{c t-1}+\Delta \mathbf{w}_{\mathbf{c}}^{\prime} \mathbf{f}_{\mathbf{c t}} e_{c t}}{2}+\frac{\mathbf{w}_{\mathbf{c t}}^{\prime} \Delta \mathbf{f}_{\mathbf{c}} e_{c t-1}+\mathbf{w}_{\mathbf{c t}-\mathbf{1}}^{\prime} \Delta \mathbf{f}_{\mathbf{c}} e_{c t}}{2} \\
+\frac{\mathbf{w}_{\mathbf{c t}}^{\prime} \mathbf{f}_{\mathbf{c t}} \Delta e_{c}+\mathbf{w}_{\mathbf{c t}-\mathbf{1}}^{\prime} \mathbf{f}_{\mathbf{c t}-\mathbf{1}} \Delta e_{c}}{2}=I E_{e}(c)+C E_{e}(c)+S E_{e}(c)
\end{gathered}
$$

Proceeding in the same way with (11) gives: 


$$
\begin{aligned}
\Delta V W M(c)= & \frac{\Delta \mathbf{w}_{\mathbf{c z}}^{\prime} \mathbf{M}_{\mathbf{c z t}-\mathbf{1}} \mathbf{b}_{\mathbf{c t}-\mathbf{1}} m_{c t-1}+\Delta \mathbf{w}_{\mathbf{c z}}^{\prime} \mathbf{M}_{\mathbf{c z t}} \mathbf{b}_{\mathbf{c t}} m_{c t}}{2} \\
& +\frac{\mathbf{w}_{\mathbf{c z t}}^{\prime} \Delta \mathbf{M}_{\mathbf{c z}} \mathbf{b}_{\mathbf{c t}-\mathbf{1}} m_{c t-1}+\mathbf{w}_{\mathbf{c z t}-\mathbf{1}}^{\prime} \Delta \mathbf{M}_{\mathbf{c z}} \mathbf{b}_{\mathbf{c t}} m_{c t}}{2} \\
& +\frac{\mathbf{w}_{\mathbf{c z t}}^{\prime} \mathbf{M}_{\mathbf{c z t}} \Delta \mathbf{b}_{\mathbf{c}} m_{c t-1}+\mathbf{w}_{\mathbf{c z t}-\mathbf{1}}^{\prime} \mathbf{M}_{\mathbf{c z t}-\mathbf{1}} \Delta \mathbf{b}_{\mathbf{c}} m_{c t}}{2} \\
& +\frac{\mathbf{w}_{\mathbf{c z t}}^{\prime} \mathbf{M}_{\mathbf{c z t}} \mathbf{b}_{\mathbf{c t}} \Delta m_{c}+\mathbf{w}_{\mathbf{c z t}-\mathbf{1}}^{\prime} \mathbf{M}_{\mathbf{c z t}-\mathbf{1}} \mathbf{b}_{\mathbf{c t}-\mathbf{1}} \Delta m_{c}}{2} \\
& =I E_{e}(c)+L E_{m}(c)+C E_{m}(c)+S E_{m}(c)
\end{aligned}
$$

Thus, changes in virtual water trade flows will be explained on the basis of the water intensity effect, measuring the contribution of variations in water intensities to changes in virtual water trade flows $\left(I E_{e}(c)\right.$ and $\left.I E_{m}(c)\right)$; the localization effect, which indicates to what extent changes in the origin of products influence the volume of water embodied in imports $\left(L E_{m}(c)\right)$; the composition effect, which links changes in virtual water trade flows to changes in product trade patterns $\left(C E_{e}(c)\right.$ and $\left.C E_{m}(c)\right)$, and the scale effect, which explains changes in virtual water trade flows depending on changes in the volume of trade $\left(S E_{e}(c)\right.$ and $\left.S E_{m}(c)\right)$.

\subsection{Data}

To obtain the components presented below, data on agricultural and food products trade published by the United Nations Statistics Division (COMTRADE, 2014) at the four digit level of the Standard International Trade Classification (SITC, revision 1) are used. We

work with 133 products for exports and imports, and with 89 commercial partners in the case of imports. COMTRADE data on trade value are deflated and expressed in constant 1985 dollars. Our sample accounts for more than 75\% of the total Spanish international trade of agricultural and food products in the period studied. As we lack data on the virtual water content of processed food goods (for example, in bakery products, pasta, processed meat, and preserved fruits), they were not included in the study. Agricultural and food production data were obtained from "Anuario Estadístico de la Producción Agraria"(MAGRAMA 1965-2010). 
In order to estimate the water coefficients for each crop, country, and period, we follow the average crop water intensities (m3/Ton) for the period 1996-2005 taken from Mekonnen and Hoekstra (2011), and the livestock water intensities (m3/Ton) taken from Mekonnen and Hoekstra (2012). These coefficients express the volume of water consumption (m3) per unit of production, measured in Tons, and are estimated as the ratio between evapotranspiration (ET) and yield (Y). These coefficients can be assumed to be representative at the country level since, as explained by Mekonnen and Hoekstra (2011, 2012), the virtual water content of crops is obtained with a high resolution level, using a grid-based dynamic water balance model applied on a global scale, using a resolution level of 5 by 5 arc minute grid size (about $10 \mathrm{~km}$ by $10 \mathrm{~km}$ at the Equator) (see Mekonnen and Hoekstra 2010 for more information on this process). However, these data can also be affected by several uncertainties. For example, they are greater than those that distinguish between irrigated and rainfed land, in a study by Garrido et al. (2010) for Spain, entailing an overestimation of the results. In fact, Hoekstra et al. (2011) point to the need to study the sensitivity and the magnitude of uncertainties in the results of a Water Footprint Assessment, in relation to the assumptions and input variables. Following this line, we can find recent studies (Bocchiola et al. 2013, Guieysse et al. 2013, Zhuo et al 2014) that examine precipitation, reference evapotranspiration, crop coefficient, crop calendar, soil water content at field capacity, yield response factor, and maximum yield as the main sources of uncertainty.

In a following step, the coefficients above are updated for the whole time span (19652010). In this regard, estimating environmental footprints (water use, land use, energy consumption) for a long-term period is a challenging topic that has been widely discussed in the scientific literature. More specifically, some work as the developed by Haberl et al. (2001) has tried to assess the different methods used to study historical ecological impacts of the long-term process of development. These authors recognize that calculating environmental footprints for a long-term span is not a straightforward application.

In our case, as shown in Duarte et al. (2014b) and in Appendix 1, while it is feasible to assume that climatic and crop characteristics in Spain, (i.e, ET) have remained relatively constant over time, technological developments such as irrigation, fertilization, and 
improvements in seeds have entailed notable yield improvements that could have affected water intensities from 1965 to 2010. As pointed out by Haberl et al. (2001), two approaches have been commonly used to obtain environmental footprints in the long term. First, some studies use fixed coefficients assuming constant yields in time (Renault 2002, Shi et al. 2014). This constancy cannot be assumed for a period such as the one analysed, with significant average improvements in the general conditions affecting the virtual water of crops (changes in irrigation techniques, changes in the share of crops, changes in the use of fertilizers...). Second, other papers estimate variable water footprints on the basis of changes in long-term crop yields. In this line, the methodology utilized in our study follows the approach of Doorenbos and Kassam (1986), and more recently by Dalin et al., (2012) and Konar et al., (2013), using crop yield series to estimate the changing virtual water content of crops as follows:

$$
w_{c p t}=w_{c p} \frac{Y_{c p}}{Y_{c p t}}
$$

Where $w_{c p t}$ is $w_{c t}^{\prime}$ the water coefficient for each product in the period of analysis $(\mathrm{t}$ from 1965 to 2010), $w_{c}^{\prime}$ represents the crop or livestock water intensity given by Mekonnen and Hoekstra (2011, 2012), $Y_{c p}$ expresses the average yield of the reference period (19962005),and $Y_{c p t}$ are the annual product yields for each specific year studied. Equation 14 assumes a decreasing, convex with respect to the origin, and hyperbolic relationship that involves the virtual water content gradually declining as crop yield increases.

The hypothesis underlying this approach is that technological advances have affected crop and livestock yields in the long term, also influencing water consumption per ton. Data on crop and livestock yields from 1965 to 2010 have been taken from the UN Food and Agriculture Organisation (FAO 2013). These series tell us of the average yield of rainfed and irrigated agriculture, which allows us to account for the agricultural improvements resulting from irrigation expansion.

There are alternative approaches, such as the interesting one developed by Rockström (2003) and Rockström et al. (2007), who assume that the ratio between the crop yield growth and the water productivity evolution changes with the level of yield (see Appendix 
1 for more detail on this issue). This method requires obtaining information on the rate of decline in evaporation with increased crop canopy, for each crop and country, in the long term, which is beyond the scope of our analysis.

\section{Results}

\subsection{Analysis of virtual water trade flows}

Figures 1 and SI1 show the evolution of virtual water trade during the period studied. As can be observed, these flows experienced continuous growth from 1965 to 2010, being particularly intense from 1986. Total virtual water exports went from 2,975 $\mathrm{Hm}^{3}$ in 1965 to $31,705 \mathrm{Hm}^{3}$ in 2009 , involving an absolute increase of $28,730 \mathrm{Hm}^{3}$. It is important to note that approximately $80 \%$ of this growth took place from 1986 . Virtual water imports experienced an increase of $27,777 \mathrm{Hm}^{3}$, from $8,064 \mathrm{Hm}^{3}$ in 1965 to $35,841 \mathrm{Hm}^{3}$ in 2010 , with 74\% of this increase being from 1986 onwards. Thus, we can say that Spain was a net importer of virtual water. Both blue and green virtual water exports increased during these years.

Figure 1: Green and blue virtual water exports and imports (1965-2010)
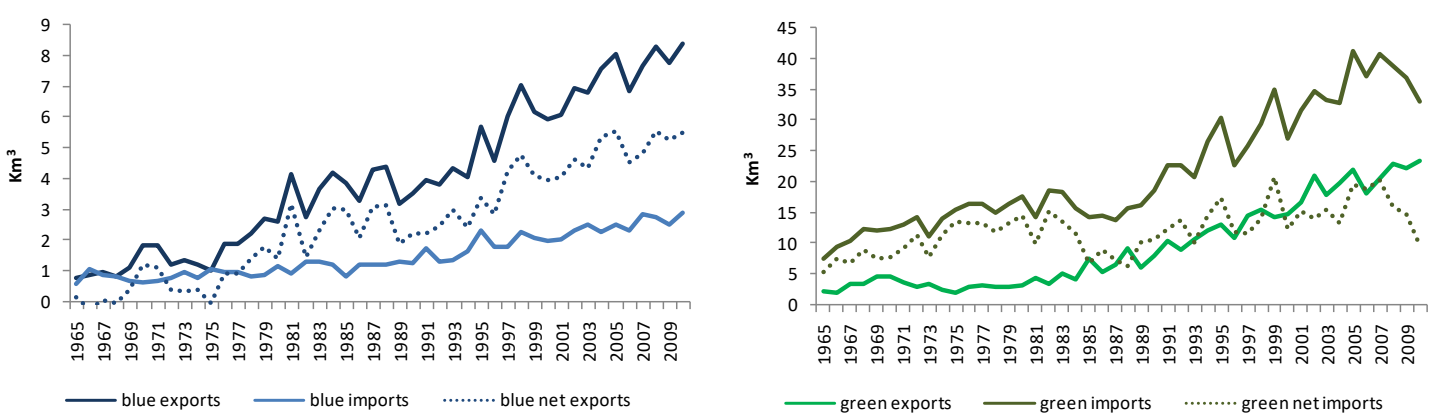

The average annual growth rate of green water exports (Figure 1) was $2.3 \%$ for the period 1965-1985, and accelerated after 1986, increasing at 5.6\% annually. Blue water exports (Figure 1) exhibit significant growth during the first 27 years $(8.2 \%)$, but this rate tended to flatten during the second period (3.9\%). Blue water represented between $30 \%$ and $40 \%$ of total water exports and reached its highest share (over 45\%) during the 1980s.Virtual water imports also display a significant increase during these years. Green water imports experienced an approximately 3.1\% annual increase between 1965 and 2010, while blue water imports grew at $2.2 \%$ until 1986 , after which the rate accelerated to $3.7 \%$. In this 
case, the share of blue virtual water imports appears to be less significant, remaining quite stable at around $7 \%$.

Comparing virtual water exports and imports, it is possible to observe that, on balance, Spain was a net exporter of blue water but a net importer of green water (Figure 1). This indicates that the impact on domestic blue water resources due to exports was greater than that generated by Spanish imports on foreign resources. For green water, we find the opposite situation. The gap between blue virtual water exports and imports is notable and appears to gradually widen during the years after accession to the European Union, and from year 2000. Interestingly, there is less of a gap between green virtual water exports and imports, which remains quite stable throughout the period studied.

On the whole, fruits and vegetables and vegetable oils represented more than $50 \%$ of both green and blue virtual water exports (Table 1). From 1965 to 2010, vegetable oils and fruits and vegetables were the most important groups with approximately $40 \%$ and $30 \%$ of blue water exports respectively, with olive oil and oranges being the most significant products. The increase in irrigated olive groves explains, to some extent, the high share of olive oil in blue water exports. As for green water, it was exported mostly through olive oil, and fruits such as oranges. The loss of share by fruits and vegetables, beverages (primarily wine) and cereals, from 1986, was partially made up by a significant increase in the share of green water embodied in meat, dairy products and eggs. Whereas the former, insignificant in 1965, rose to $15.5 \%$ of total green exports from 1986, growing at $11.1 \%$ every year, the latter displayed modest growth, increasingly sharply after 1986 to a growth rate of $10 \%$.

\section{Insert Table $\mathbf{1}$}

Table 1 shows a notable loss of share of water embodied in traditional Mediterranean export products, fruits and vegetables, and wine, in favour of goods like meat, dairy products, and eggs (those three categories have become more common in everyday diets in recent years). As we have explained, the change in demand patterns, caused by rising incomes, is associated with a notable growth of meat and milk production. During the 
1990s and the first decade of the $21^{\text {st }}$ century, Spain began to export considerable volumes of these products, particularly of pork and pork-derived products. 


\section{Table 1: Virtual water exports and imports by group of products (average share and average annual growth rates \%)}

\begin{tabular}{|c|c|c|c|c|c|c|c|c|}
\hline \multirow{5}{*}{ Sitc rev. 1 products classification } & \multicolumn{8}{|c|}{ Virtual water exports } \\
\hline & \multicolumn{4}{|c|}{ Share } & \multicolumn{4}{|c|}{ Growth } \\
\hline & \multicolumn{2}{|c|}{ Green water } & \multicolumn{2}{|c|}{ Blue water } & \multicolumn{2}{|c|}{ Green water } & \multicolumn{2}{|c|}{ Blue water } \\
\hline & 1965- & 1986- & 1965- & 1986- & 1965- & 1986- & 1965- & 1986- \\
\hline & 1985 & 2010 & 1985 & 2010 & 1985 & 2010 & 1985 & 2010 \\
\hline 00 Live animals & 4.17 & 3.23 & 2.7 & 1.09 & $\begin{array}{l}-13.2 \\
\end{array}$ & 13.6 & -14.3 & 11.9 \\
\hline 01 Meat and meat preparations & 2.8 & 15.55 & 1.05 & 4.6 & 13.7 & 18 & 16.6 & 19.8 \\
\hline 02 Dairy products and eggs & 1.62 & 5.91 & 0.32 & 2.05 & 12.7 & 17.2 & 24.9 & 17 \\
\hline 04 Cereals and cereal preparations & 13.6 & 9.61 & 7.6 & 9.99 & -0.6 & 4.6 & 0.2 & 6.1 \\
\hline 05 Fruit and vegetables & 29.99 & 19.06 & 28.74 & 28.08 & 2.1 & 4.5 & 4.8 & 4.9 \\
\hline 06 Sugar, sugar preparations and honey & 0.16 & 0.7 & 0.47 & 2.22 & 46.8 & -3.6 & 60.1 & -3.6 \\
\hline 07 Coffee, tea, cocoa, spices \&manufacs. thereof & 0.92 & 0.37 & 1.52 & 0.65 & 6.9 & 2.1 & 4.4 & 1.7 \\
\hline 08 Feed Stuff for animals excl. unmilled cereals & 2.1 & 1.19 & 3.05 & 3.06 & 34.1 & 5.2 & 27.3 & 5.2 \\
\hline 11 Beverages & 15.76 & 6.76 & 5.7 & 2.93 & 3.1 & 4.4 & 2.6 & 4.4 \\
\hline 1210 Tobacco, unmanufactured & 0.01 & 0.11 & 0 & 0.08 & 30.3 & 16.6 & 23.2 & 16.6 \\
\hline 21 Hides and fur skins, undressed & 0.36 & 1.61 & 0.06 & 0.34 & -1.1 & 6.9 & 4.6 & 6.7 \\
\hline 22 Oil seeds, oil nuts and oil kernels & 0.25 & 0.79 & 1.12 & 2.18 & 9.2 & 14.9 & 13.4 & 18.6 \\
\hline 26 Textile fibres, not manufactured, and waste & 0.23 & 0.31 & 2.07 & 3.79 & 14.8 & 3.9 & 16.6 & 4.2 \\
\hline 29 Crude animal and vegetable materials, nes & 0.05 & 0.01 & 0.01 & 0 & 13.4 & -17.4 & 17.3 & -17.4 \\
\hline 42 Fixed vegetable oils and fats & 27.19 & 33.59 & 45.25 & 38.51 & 18.7 & 4.2 & 20.5 & 1.9 \\
\hline 59 Chemical materials and products, nes & 0.21 & 0.14 & 0.23 & 0.15 & n.a. & 16.1 & n.a. & 17 \\
\hline 61 Leather, lthr. Manufs., nes \& dressed fur skins & 0.55 & 1.05 & 0.09 & 0.25 & 9.3 & 10.3 & 9.6 & 10.1 \\
\hline Total & 100 & 100 & 10 & 100 & 6.3 & 6.2 & $\overline{7.5}$ & 4 \\
\hline
\end{tabular}

2 Source:

Virtual water imports

\begin{tabular}{rrrrrrrr}
\multicolumn{4}{c}{ Share } & \multicolumn{5}{c}{ Growth } \\
\hline \hline \multicolumn{2}{c}{ Green water } & \multicolumn{2}{c}{ Blue water } & \multicolumn{2}{c}{ Green water } & \multicolumn{2}{c}{ Blue water } \\
$\mathbf{1 9 6 5 -}$ & $\mathbf{1 9 8 6 -}$ & $\mathbf{1 9 6 5 -}$ & $\mathbf{1 9 8 6}$ & $\mathbf{1 9 6 5 -}$ & $\mathbf{1 9 8 6}-$ & $\mathbf{1 9 6 5 -}$ & $\mathbf{1 9 8 6 -}$ \\
$\mathbf{1 9 8 5}$ & $\mathbf{2 0 1 0}$ & $\mathbf{1 9 8 5}$ & $\mathbf{2 0 1 0}$ & $\mathbf{1 9 8 5}$ & $\mathbf{2 0 1 0}$ & $\mathbf{1 9 8 5}$ & $\mathbf{2 0 1 0}$ \\
\hline \hline 0.24 & 1.82 & 0.15 & 1.61 & 12.5 & 1.4 & 6.9 & 2.7 \\
7.08 & 4.43 & 3.02 & 3.32 & -4.8 & 3.4 & -2.4 & 3.6 \\
3.26 & 3.5 & 3.85 & 4.98 & 1.4 & 4.7 & 1.3 & 6.1 \\
34.74 & 20.81 & 35.3 & 24.23 & 0.8 & 5.6 & -0.7 & 1.8 \\
1.41 & 5.91 & 3.31 & 13.87 & 1.4 & 7.1 & 9.6 & 7.6 \\
0.15 & 0.4 & 0.49 & 6.03 & 6.1 & 10.5 & 25.8 & 12.8 \\
13.77 & 10.27 & 0.7 & 1.05 & 5.9 & -0.7 & 10.1 & 4.2 \\
2.96 & 14.72 & 4.82 & 14.25 & 13.8 & 3.7 & 10.6 & 2 \\
0.27 & 0.97 & 0.57 & 0.37 & 0.5 & -3.3 & 9.9 & 2.3 \\
0.73 & 0.26 & 0.12 & 0.16 & 3.7 & -2.7 & 6.6 & 0.8 \\
2 & 1.3 & 1.19 & 0.89 & 7.4 & 1.7 & 4.3 & 1.2 \\
26.62 & 21.79 & 18.8 & 11.63 & 1.1 & -6 & -0.7 & -9.6 \\
3.01 & 1.27 & 25.28 & 7.99 & -3.3 & 10.8 & -5.1 & 12.6 \\
0.02 & 0.02 & 0.02 & 0.02 & 27.1 & 2.7 & 28.2 & 10.8 \\
3.16 & 9.69 & 1.96 & 7.43 & 24.2 & 6.9 & 24.7 & 5.1 \\
0.03 & 0.07 & 0.01 & 0.06 & n.a. & 42.9 & n.a. & 50.1 \\
0.54 & 2.74 & 0.38 & 1.99 & -14.8 & 10.5 & 4 & 6.2 \\
\hline \hline $\mathbf{1 0 0}$ & $\mathbf{1 0 0}$ & $\mathbf{1 0 0}$ & $\mathbf{1 0 0}$ & $\mathbf{3 . 3}$ & $\mathbf{3 . 5}$ & $\mathbf{1 . 8}$ & $\mathbf{3 . 7}$ \\
\hline \hline
\end{tabular}

elaboration 
Looking at the composition of imports (Table 1), we observe that during the period 19652010, Spain imported water embodied basically in cereals, coffee and cocoa, soy beans, and fruits and vegetables. Green water was embodied mainly in imports of soy beans, coffee, and cereals, with maize being the main crop. These products accounted for $70 \%$ of green virtual water imports, on average. From 1986, Spain continued to import green water in this form, but these three groups underwent a notable loss of share that was offset by the increase of water embodied in feed stuff, fruit and vegetables, and vegetable oils. Most products comprising the increase in imports were used as feed stuff for intensive farming.

Regarding blue virtual water imports, cereals (with maize as the most important) entailed over 35\% of these flows between 1962 and 1985. Textile fibres, mostly cotton, and soy beans also had a considerable influence on blue water imports. These water-intensive crops made a notable contribution during the whole period. From1986, cereals, soy beans, and cotton were still the most representative groups, although their share fell significantly; imports of blue water through fruits and vegetables and feed stuff (oil seed cake, etc.) were more important. Feed stuff also had a significant share in blue virtual water imports, but the high level of development led Spain to become an importer of fresh fruits and vegetables.

The growth of intensive livestock farming in Spain, first to meet domestic demand, led to a sharp increase in imports of feed for livestock, and as Spain became a major exporter of meat, the expansion of livestock production and exports led to a substantial increase in imports of green virtual water (Garrido et al., 2010; Ríos-Nuñez et al., 2013).

As we have seen, an important change in trade patterns took place from 1965 to 2010 in Spain, not only in terms of product composition, but also, although to a lesser extent, in terms of the origin of those products. In the 1960s, 34\% of green water (Figure SI2) was imported from the United States, embodied mainly in soy beans and maize, or from Argentina and Brazil (22\% and $10 \%$ of total green water imports) transferred in virtual form through cereals such as wheat and maize, and coffee from Brazil. These countries continue to be important providers of green water for Spain (Figure SI3) with 18\% and $13 \%$ of Spanish green water imports from Argentina and Brazil, respectively. Today Spain 
32 buys the bulk of its soy beans from Brazil, and its oil seed cake from Argentina, while

33 France is the source of 8\% of Spain's imports of green water, embodied in maize and wheat.

34 The change in the origin of blue water products was more marked (Figures SI4 and SI5). At

the beginning of the period analysed, blue virtual water flows from the US were 34\% of total blue water imports. Maize and soy beans were the most significant traded goods, together with cotton, an intensive blue water crop, that mostly came from Egypt and Turkey. Blue water imports from these two nations accounted for approximately $24 \%$ of the total. The accession of Spain to the European Community entailed a gradual loss of share from the Americas, in favour of its new European partners. Currently, Portugal, with $30 \%$ of total blue water imports is the main provider of blue water in Spain, through sugar, sunflower oil, and oil seed cake. Spain also imported blue water through cereals and soy beans from the US, while France became an outstanding provider of maize, representing $12 \%$ of Spain's total blue virtual water imports.

\subsection{Decomposition analysis of virtual water trade of flows}

As we have seen, Spain underwent an intense opening up of trade, from 1965 to 2010, that entailed an unprecedented increase in virtual water imports and exports. This growth accelerated after 1986, when Spain became a member of the European Union. In this section, we analyse the driving forces behind the increase in virtual water flows, through a Decomposition Analysis.

Table 2 shows that the total increase of water embodied in exports was about $27.6 \mathrm{Km}^{3}$ from 1965 to 2010, and it is interesting to note that the increase in total virtual water exports exceeds virtual water imports. Despite the fact that Spain continued to be a net importer of water, its negative water balance decreased, which may seem paradoxical, given the country's natural aridity. This growth was particularly intense from 1986, accounting for $22 \mathrm{Km}^{3}$, representing $80 \%$ of the total. On the whole, the great commercial expansion of these years, i.e. the scale effect, triggered the increase in both blue and green virtual water exports. Meanwhile, trade pattern changes, as well as yield improvements, contributed significantly to the moderation of water consumption increases. 
Table 2: Decomposition analysis of virtual water flows.

\begin{tabular}{llrrr}
\hline \hline & \multicolumn{1}{c}{ Effects } & 1965-1985 & 1986-2010 & 1965-2010 \\
\hline \hline Green virtual water exports & Composition (\%) & -31 & 3 & -15 \\
& Scale (\%) & 115 & 131 & 134 \\
& Intensity (\%) & 17 & -34 & -19 \\
& $\Delta$ VWE (Km3) & 2.79 & 17.50 & 20.29 \\
Blue virtual water exports & Composition (\%) & 51 & -140 & -8 \\
& Scale (\%) & 57 & 278 & 127 \\
& Intensity (\%) & -8 & -38 & -19 \\
& $\Delta$ VWE (Km3) & 2.81 & 4.53 & 7.35 \\
\hline \hline Green virtual water imports & Composition (\%) & -3 & -67 & -54 \\
& Scale (\%) & 153 & 177 & 187 \\
& Localization (\%) & -6 & 16 & -7 \\
& Intensity (\%) & -43 & -26 & -26 \\
& $\Delta$ VWM (Km3) & 5.65 & 18.83 & 24.48 \\
Blue virtual water imports & Composition (\%) & -28 & -16 & -52 \\
& Scale (\%) & 276 & 161 & 215 \\
& Localization (\%) & -63 & -37 & -61 \\
& Intensity (\%) & -84 & -7 & -1 \\
& $\Delta$ VWM (Km3) & 0.26 & 1.56 & 1.81 \\
\hline \hline
\end{tabular}

Source: Own elaboration

63 If we look at green virtual water exports, representing more than $70 \%$ of the total water 64 increase, it is clear that, again, the growing volume of trade (scale effect) is the most 65 important explanatory factor. The composition effect encouraged the reduction of green 66 virtual water exports until 1985, but could not offset the boost provided by the scale factor. 67 From 1986, increasing exports of green water-intensive products, such as meat, led the composition effect. All other things being constant, the expansion of trade would have 69 generated an increase in water consumption of 134\% from 1965 to the present, but the technological changes that took place from 1986 resulted in growing yields and partially

71 moderated the increasing consumption of water resources. These changes reduced green 72 water consumption by approximately $3.9 \mathrm{Km}^{3}$. Changes in the product mix traded also 73 contributed to alleviate water pressures in the first part of the period, while boosting water 74 consumption from 1986. 
Blue virtual water exports also rose from 1965 to 2010, although to a lesser extent. In general, considering the whole period, the scale effect encouraged blue virtual water export expansion, while the composition and intensity effects prevented greater water consumption. We see some differences when examining the two different periods: from 1965 to 1985, both scale and composition effects boosted blue virtual water exports, triggered by the growth of trade in exports of blue water intensive products like fruits and vegetables, while the reduction of water intensities contributed to a partial levelling-off. Nonetheless, from 1986, the great increase seen in blue virtual water exports was largely due to the rise in the volume of trade, since both the composition and intensity effects show negative signs.

Tuning to virtual water imports, Table 2 shows a significant increase taking place particularly from 1986. In fact, virtual water imports grew by about $26 \mathrm{Km}^{3}$ during these years of intense internationalization in Spain, and the increase experienced from 1986 was about $77 \%$ of the total. Spain imported mostly green water, which on average represented 93\% of total water imports. The rise in green water imports was driven mostly by the scale effect, whereas the composition, localization, and intensity effects contributed to virtual water imports levelling off. That is to say, from 1965 to 2010, Spain increased its volume of green water embodied in imports as a result of its broad globalizing process. Changes in trade patterns, with decreasing imports of oil seed, coffee, and cereals were a determining element in water consumption moderation. Yield improvements in the producing nations were also beneficial for water resources from 1965 to 2010. Despite that the localization effect was also negative until 1985, accession to the EU and the consequent changes in the origin of products (greater trade with geographically close areas such as France and Portugal) led to an increase in green water embodied in imports. As Table3 shows, blue water imports only represented about $6 \%$ of the increase in total virtual water imports. The scale effect triggered the rise from 1965 to 2010 and as happened with green water, the composition, intensity, and localization effects prevented a greater increase in blue virtual water imports. Thus, Spain was importing more blue water because of the increasing exchange of commodities, with the localization effect being the most important negative factor, since there was a significant variation in the countries of origin of blue 
water imports. As we have seen, countries that produce cotton in a water-intensive way, Egypt and Turkey, were important commercial partners of Spain in the 1960s. Today, these areas are less important and Spain imports most of its blue water from the US, France, and Portugal.

\section{Discussion}

As we have seen, virtual water flows in Spain followed a rising trend from 1965 to 2010, driven by a significant increase in the volume of trade. To what extent did this long term process of internationalization influence the consumption of water in Spain? Put another way, was the foreign sector a determinant of the increase in water consumption? To address this issue, let us compare the water embodied in virtual water flows with the volume of water embodied in Spanish agricultural and food production. To approximate this, we calculate the water embodied in production using data from "Anuario Estadístico de la Producción Agraria" (1965-2010) (Duarte et al., 2014c). Production data for the selected year have been obtained as a three-year average, centered on the year of reference, in an effort to reduce production volatility, and the water intensity coefficients are taken from Mekonnen and Hoekstra (2011; 2012). Table 3 offers an overview of the volume of water required for the production of agricultural and food products, and the water embodied in Spanish exports and imports.

As we can see, in 1965 green and blue virtual water exports represented $4.2 \%$ and 5\% of green and blue embodied water in total production, respectively. These percentages were lower than those reported for 1930 in Duarte et al. (2014b), which highlights the negative effect of the depression of the 1930s, the Spanish Civil War, and the Second World War, but predominantly the results of the autarkic policies of the first two decades of the Franco dictatorship. These involved a significant isolation of the Spanish economy and its agricultural sector, which, apart from having declined in foreign markets, oriented its production to domestic markets to a greater extent than before. These percentages increased by the end of the period of study, reaching approximately 30\%, particularly in the case of blue water. This major expansion of virtual water exports underlines the importance of the integration of the agricultural sector into international markets during 
134 the second globalization (Clar et al. 2015). The rise of Spanish agrifood exports was even 135 greater than that of the world agrifood trade, which experienced major growth itself 136 throughout the second half of the $20^{\text {th }}$ century (Serrano and Pinilla 2010). During these 137 years, the volume of blue water embodied in production grew by $7,600 \mathrm{Hm}^{3}$, whereas blue 138 virtual water exports increased by about $6,448 \mathrm{Hm}^{3}$, indicating that $85 \%$ of the increase in 139 blue water consumption for production was due to the growth in Spanish exports. As for 140 green water, the pressure of the foreign sector on domestic resources was less intense, 141 since that ratio reached 70\%. If we consider the volume of imported blue water, the 142 increase of net exports explains $60 \%$ of the rise in the volume of blue water embodied in 143 production.

Table 3: Comparison of blue water embodied in exports and production $\left(\mathrm{Hm}^{3}\right)$

\begin{tabular}{|c|c|c|c|c|c|c|c|}
\hline & EWP & VWX & VWM & VWB & VWX/ EWP & VWM/ EWP & VWB/ EWP \\
\hline \multicolumn{8}{|l|}{ Green water } \\
\hline 1966 & 54,682 & 2,288 & 9,064 & $-6,776$ & 4.2 & 16.6 & -12.4 \\
\hline 2008 & 79,952 & 20,070 & 36,205 & $-16,134$ & 25.1 & 45.3 & -20.2 \\
\hline \multicolumn{8}{|l|}{ Blue water } \\
\hline 1966 & 14,353 & 711 & 864 & -153 & 5.0 & 6.0 & -1.1 \\
\hline \multirow[t]{2}{*}{2008} & 21,953 & 7,159 & 2,704 & 4,456 & 32.6 & 12.3 & 20.3 \\
\hline & $\Delta \mathrm{EWP}$ & $\Delta V W X$ & $\Delta \mathrm{VWM}$ & $\Delta$ VWB & $\Delta V W X / \Delta$ EWP & $\Delta V W M / \Delta$ EWP & $\Delta \mathrm{VWB} / \Delta \mathrm{EWP}$ \\
\hline \multicolumn{8}{|l|}{ Green water } \\
\hline 1966-2008 & 25,270 & 17,783 & 27,141 & $-9,359$ & 70.4 & 107.4 & -37.0 \\
\hline \multicolumn{8}{|l|}{ Blue water } \\
\hline 1966-2008 & 7,600 & 6,448 & 1,840 & 4,609 & 84.8 & 24.2 & 60.6 \\
\hline
\end{tabular}
balance: VWX-VWM. As we do not have data on manufactured crops and livestock production, these items have not been included in virtual water exports for comparability reasons. 152 enormous weight of external demand (or net balance of trade in blue virtual water) in the 153 Spanish economy are significant: water policy formed an important part of the Franco 154 dictatorship's (1939-75) agricultural policy. This was based on earlier irrigation plans that 155 required the construction of ever larger dams, leading to a major expansion in the area of 
irrigated land. The construction of dams to store water for irrigation accelerated between 1951 and 1990, particularly during the 1950s and '60s. Between 1951 and 1990, the capacity of such dams increased by $24,500 \mathrm{Hm}^{3}$, about $80 \%$ of the current storage capacity. The period studied is therefore crucial for the expansion of large waterworks in Spain. As a consequence, the area of irrigated farmland grew rapidly, and by 1995 it was 133\% greater than before the Civil War (Pinilla 2006). The fact that the irrigated area more than doubled over the period analyzed was mostly due to the high foreign demand for agrifood products, and to the capacity of the agricultural sector to meet these needs. Nonetheless, the development of large irrigation schemes, involving the construction of large dams, canals, and irrigation networks entailed a formidable public and private investment, with public sector funding being increasingly dominant. As an example, all of the large dams in the region of Aragon, in the Ebro watershed, with more than 20\% of Spain's irrigated area were built between 1960 and 1990 (Ibarra and Pinilla 1999: 408).

It is also necessary to examine the impact of the increase in irrigated agriculture on the natural environment, especially in the last 30 years. Some of the major environmental impacts affecting water resources were the salinity of the agricultural land, the problems of preserving the river deltas (as a result of the decline in the volume of water flows), and the contribution to widespread pollution of water by nitrates and phosphates due to the intensive use of chemical fertilizers and phytosanitary products (Duarte et al.2002; Pinilla 2008).

However, despite the impact of the second globalization on blue water domestic resources, it is important to note that Spain was a net importer of water. That is, in spite of exporting large volumes of blue water, growing imports of green water embodied in cereals and feed stuff contributed to alleviate the impact on domestic water resources.

\section{Conclusions}

From 1965 to 2010, Spain experienced profound economic, political, and social change. From an economic perspective, the culmination of the processes of industrialization and economic modernization meant that Spain would become a high-income country (Prados de la Escosura and Rosés 2009). Although the food industry lost share, both in overall 
economic activity and in external trade flows, it also experienced significant changes, the most important being the transformation of traditional agriculture into a modern and highly productive sector (Clar and Pinilla 2009). Agrifood exports and imports grew at a fast pace, exceeding previous periods (Clar et al. 2015). In this context, our work contributes to the existing literature by giving a long term perspective on the link between trade expansion and trends in the consumption of water resources, and the growing integration of Spain into international markets entailed large pressures on both domestic and foreign water resources. Over the course of the period studied, Spain was a net exporter of blue water, with growth in net exports over $60 \%$ of the growth of blue water embodied in production. On balance, Spain imported large volumes of green water, meaning that, as a whole, Spain exerted substantial pressure on foreign resources. The growing commercial exchanges were the determining factor driving virtual water trade flows. Despite the fact that yield improvements, compositional pattern changes, and variations in the origin of products had a significant contribution, these effects were not enough to offset the large increase in the volume of trade.

Given the great pressure exerted on water resources, the main solution adopted was an increase in the regulated water supply, that is, construction of large reservoirs and canals to facilitate development of irrigation, while most of the increase in agriculture was due to the expansion of Spanish agrifood exports, resulting in large public and private investments, and significant environmental impacts.

As we have seen, the growing integration of Spain into international markets led to an increasing consumption of water. Although it is true that there exist factors that appear to slow down the consumption of water resources, that consumption is still growing today. Against this background, it is necessary for countries to assess the environmental consequences of long-term socio-economic transitions. Furthermore, it is crucial to take into account that, in the current globalized context, the consumption of products in one region may entail serious social and environmental problems in another. This is particularly important for those developing countries that have abundant natural resources and are experiencing rapid economic growth, with substantial foreign sector factors in their national GDP. 


\section{Acknowledgements}

216 The authors wish to thank Gloria Jarne for her help and advice with the previous versions 217 of this paper. This work has been partially supported by a doctoral grant from the 218 Government of Spain and by the Ministry of Science and Innovation of the Spanish 219 Government, projects ECO 2012-3328 and EC02010-14929, and the Department of 220 Science, Technology and Universities of the Government of Aragon and the European 221 Social Fund to the Research Group for 'Agrifood Economic History' and the Research Group 222 "Growth, Demand and Natural Resources". Earlier versions of this paper were presented at 223 the XIV International Conference of the Spanish Agricultural Society, and the 7th European 224 Society for Environmental History (ESEH) Conference. The authors also thank two 225 anonymous referees for their helpful comments. The usual disclaimers apply.

\section{References}

227

Aldaya M, Garrido A, Llamas MR, Varela-Ortega C, Novo P, Rodríguez Casado R (2008) The water footprint of Spain Journal on Sustainable Water Management 3: 15-20.

229

Aldaya M, Garrido A, Llamas MR, Varela-Ortega C, Novo P, Rodríguez Casado R (2010) 230 Water footprint and virtual water trade in Spain. In: Water policy in Spain. CRC Press/Balkema, Boca Raton, FL, pp 49-59

Allan JA (1993) Fortunately there are substitutes for water otherwise our hydro-political futures would be impossible. In: ODA, Priorities for water resources allocation and management. ODA, London, pp 13-26

Antweiler W, Copeland BR, Taylor MS (2001) Is Free Trade Good for the Environment? American Economic Review 91:877-908. doi: 10.1257/aer.91.4.877

Bocchiola D, Nana E, Soncini A (2013) Impact of climate change scenarios on crop yield and water footprint of maize in the Po valley of Italy, Agricultural Water Management 116: 50-61. doi: 10.1016/j.agwat.2012.10.009 
Clar E, Pinilla V (2009) The contribution of agriculture to Spanish economic development. In: Lains P, Pinilla V (eds) Agriculture and Economic Development in Europe since 1870. Routledge, London, pp 311-332

Clar E, Pinilla V, Serrano R (2015) El comercio agroalimentario español en la segunda globalización, 1951-2011 Historia Agraria 65

COMTRADE database.http://comtrade.un.org/db/ Accesed: January 2014

Dalin C, Konar M, Hanasaki N, Rinaldo A, Rodriguez-Iturbe I (2012) Evolution of the global virtual water trade network Proceedings of the National Academy of Sciences 109:59895994. doi:10.1073/pnas.1203176109

Dietzenbacher E, Los B (1998) Structural Decomposition Techniques: Sense and Sensitivity Economic Systems Research 10:307-324. doi:10.1080/09535319800000023

Duarte R, Pinilla V, Serrano A (2013) Is there an environmental Kuznets curve for water use? A panel smooth transition regression approach Economic Modelling 31:518-527. doi: 10.1016/j.econmod.2012.12.010

Duarte R, Pinilla V, Serrano A (2014a) Looking backward to look forward: water use and economic growth from a long-term perspective Applied Economics 46:212-224. doi:10.1080/00036846.2013.844329

Duarte R, Pinilla V, Serrano A (2014b) The effect of globalisation on water consumption: a case study of the Spanish virtual water trade, 1849-1935 Ecological Economics 100:96105. doi: j.ecolecon.2014.01.020

Duarte R, Pinilla V, Serrano A (2014c) The water footprint of the Spanish agricultural sector: 1860-2010 Ecological Economics 108: 200-207. doi:10.1016/j.ecolecon.2014.10.020

Duarte R, Sánchez-Chóliz J, Bielsa J (2002) Water use in the Spanish economy: an inputoutput approach Ecological Economics 43:71-85. doi:10.1016/S0921-8009(02)00183-0 
265 Erb K-H (2012) How a socio-ecological metabolism approach can help to advance our 266 understanding of changes in land-use intensity Ecological Economics 76:8-14 267 doi:j.ecolecon.2012.02.005

268

269

270

271

272

273

274

275

276

277

278

279

280

281

282

283

284

285

286

287

288

289

290

291

Fader M., Gerten D, Thammer M, ,Heinke J, Lotze-Campen H, Lucht W, Cramer W (2011) Internal and external green-blue agricultural water footprints of nations, and related water and land savings through trade Hydrology and Earth System Sciences 15: 16411660 doi: 10.5194/hess-15-1641-2011

FAO (2013) FAO database. http://faostat3.fao.org/faostat-gateway/go/to/home/E Accesed: January 2014

Garrido A, Llamas MR, Varela-Ortega C, Novo P, Rodríguez-Casado R, Aldaya MM (2010) Water footprint and virtual water trade in Spain: policy implications Natural Resource Management and Policy Series, Springer-Fundación Marcelino Botín. doi: 10.1007/9781-4419-5741-2_1

Gleick PH (2010) Roadmap for sustainable water resources in southwestern North America Proceedings of the National Academy of Sciences of the United States of America.doi: 107:21300-21305

Guieysse B, Béchet Q, Shilton A (2013) Variability and uncertainty in water demand and water footprint assessments of fresh algae cultivation based on case studies from five climatic regions Bioresource Technology 128: 317-323. doi.org/10.1016/j.biortech.2012.10.096

Hoekstra AY (2010) The relation between international trade and freshwater scarcity WTO working paper series.

Hoekstra AY, Chapagain AK, Aldaya MM, Mekonnen MM (2011) The water footprint assessment manual: Setting the global standard. Earthscan, London,UK

Hoekstra AY, Hung PQ (2005) Globalisation of water resources: International virtual water flows in relation to crop trade Global Environmental Change 15:45-56. doi:10.1016/j.gloenvcha.2004.06.004 
292 Ibarra P, Pinilla V (1999) Regadío y transformaciones agrarias en Aragón, 1880-1990. In:

293 Garrabou R, Naredo JM (eds) El agua en los sistemas agrarios. Una perspective histórica. 294 Visor/Argentaria, Madrid, pp 391-426

295

296

297

298

299

300

301

302

303

304

305

306

307

308

309

310

311

312

313

314

315

316

317

Iriarte-Goñi I, Ayuda M-I (2012) Not only subterranean forests: Wood consumption and economic development in Britain (1850-1938) Ecological Economics 77:176184.doi:10.1016/j.ecolecon.2012.02.029

Katerji N, Mastrorilli M, Rana G (2008) Water use efficiency of crops cultivated in the Mediterranean region: Review and analysis European Journal of Agronomy 28:493507.doi:10.1016/j.eja.2007.12.003

Konar M, Hussein Z, Hanasaki N, Mauzerall DL, Rodriguez-Iturbe I (2013) Virtual water trade flows and savings under climate change Hydrol Earth Syst Sci Discuss 10:67101.doi:10.5194/hessd-10-67-2013

Krausmann F, Schandl H, Sieferle RP (2008) Socio-ecological regime transitions in Austria and the United Kingdom Ecological Economics 65:187-201. doi: 10.1016/j.ecolecon.2007.06.009

Lenzen M, Wiedmann T, Barney F, Dey C, Widmer-Cooper A, Williams M, R O (2001) Forecasting the Ecological Footprint of Nations: a blueprint for a dynamic approach.

MAGRAMA (1965-2010) Anuario Estadístico de la Produccion Agraria http://www.magrama.gob.es/es/estadistica/temas/publicaciones/anuario-deestadistica/default.aspx. Accessed: December 2013.

Martín-Retortillo M, Pinilla V (2015 a) Patterns and causes of growth of European agricultural production, 1950-2005 Agricultural History Review 63.

Martín-Retortillo M, Pinilla V (2015 b) On the causes of economic growth in Europe: why did

agricultural labour productivity not converge between 1950 and 2005? Cliometrica DOI 10.1007/s11698-014-0119-5 
Marull J, Pino J, Tello E, Cordobilla MJ (2010) Social metabolism, landscape change and land-use planning in the Barcelona Metropolitan Region Land Use Policy 27:497-510. doi: 10.1016/j.landusepol.2009.07.004

Mekonnen M, Hoekstra A (2012) A Global Assessment of the Water Footprint of Farm Animal Products Ecosystems 15:401-415.doi:10.1007/s10021-011-9517-8

Mekonnen MM, Hoekstra AY (2011) The green, blue and grey water footprint of crops and derived crop products Hydrol Earth Syst Sci 15:1577-1600. doi:10.5194/hess-15-15772011

O'Rourke KH, Williamson JG (1999) Globalisation and History: The Evolution of a Nineteenth Century Atlantic Economy. Cambridge MA: MIT Press.

Pinilla V (2006) The development of irrigated agriculture in twentieth-century Spain: A case study of the Ebro basin Agricultural History Review 54:122-141

Pinilla V (2008) Gestión y usos del agua en el siglo XX. Un estudio de caso: la Cuenca del Ebro. In: Pinilla V (ed) Gestión y usos del agua en la Cuenca del Ebro en el siglo XX. Prensas Universitarias de Zaragoza, Zaragoza, pp 7-36

Pinilla V, Ayuda MI (2002) The political economy of the wine trade: Spanish exports and the international market, 1890-1935 European Review of Economic History 6:51-85. doi: $10.1017 / S 1361491602000035$

Pinilla V, Ayuda MI (2010) Taking advantage of globalization? Spain and the building of the international market in Mediterranean horticultural products, 1850-1935 European Review of Economic History 14:239-274. doi: 10.1017/S136149161000002X

Prados de la Escosura L, Rosés JR (2009) The Sources of Long-Run Growth in Spain, 18502000 The Journal of Economic History 69:1063-1091. doi:10.1017/S0022050709001387 
342 Ramón R (2000) Specialization in the International Market for Olive Oil before World War 343 II, in: Pamuk, S., Williamson, J.G. (Eds.), The Mediterranean Response to Globalisation 344 Before 1950. Routledge, London, pp. 159-198.

345 346

347

348

349 350

351

352

353

354

355

356

357

358

359

360

361

362

363

364

365

366

Ríos-Nuñez S, Coq-Huelva D, García-Trujillo R (2013) The Spanish livestock model: A coevolutionary analysis Ecological Economics 93: 342-350. Doi: /10.1016/j.ecolecon.2013.06.019

Rubio MdM, Folchi M (2012) Will small energy consumers be faster in transition? Evidence from the early shift from coal to oil in Latin America. Energy Policy 50:5061.doi:10.1016/j.enpol.2012.03.054

Serrano R, Pinilla V (2010) Causes of world trade growth in agricultural and food products, 1951-2000: a demand function approach. Applied Economics 42:35033518.doi:10.1017/S0212610911000103

Steen-Olsen K, Weinzettel J, Cranston G, Ercin AE, Hertwich EG (2012) Carbon, land, and water footprint accounts for the european union: Consumption, production, and displacements through international trade Environmental Science and Technology. doi:46:10883-10891

Tello E, Ostos J (2012) Water consumption in Barcelona and its regional environmental imprint: a long-term history (1717-2008) Regional Environmental Change 12: 347-361. doi: 10.1007/s10113-011-0223-z

UN (2009) United Nations World Water Assessment Programme. The World Water Development Report 3: Water in a Changing World UNESCO: Paris, France

UNWCED (1987) Our Common Future (Brundtland Report). Oxford

Yang H, Wang L, Zehnder AJB (2007) Water scarcity and food trade in the Southern and Eastern Mediterranean countries Food Policy 32:585-605. doi: 10.1016/j.foodpol.2006.11.004 
367 L. Zhuo, M. M. Mekonnen, and A. Y. Hoekstra (2014) Sensitivity and uncertainty in crop 368 water footprint accounting: a case study for the Yellow River basin Hydrology and Earth System Sciences 18: 2219-2234. doi: 10.5194/hessd-11-135-2014

370 


\section{Supplementary information}

372 Figure SI1: Total virtual water exports and imports (1965-2010)

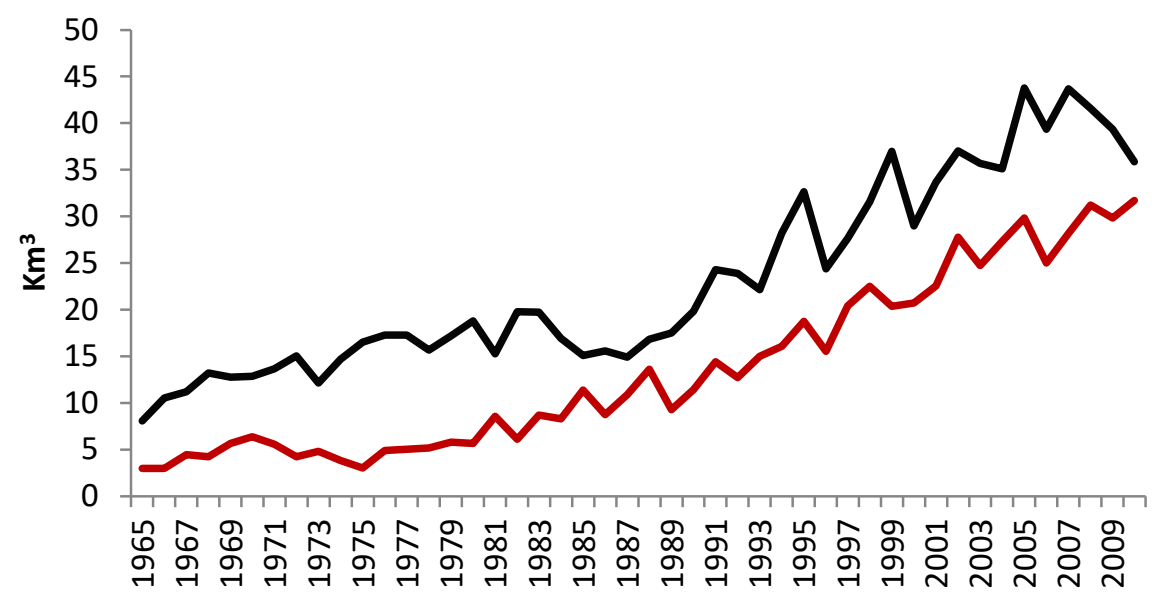

373

total exports $\longrightarrow$ total imports

374 Figure SI2: Origin of green water embodied in products imported by Spain, 1965 (thousand $\mathbf{m}^{3}$ )

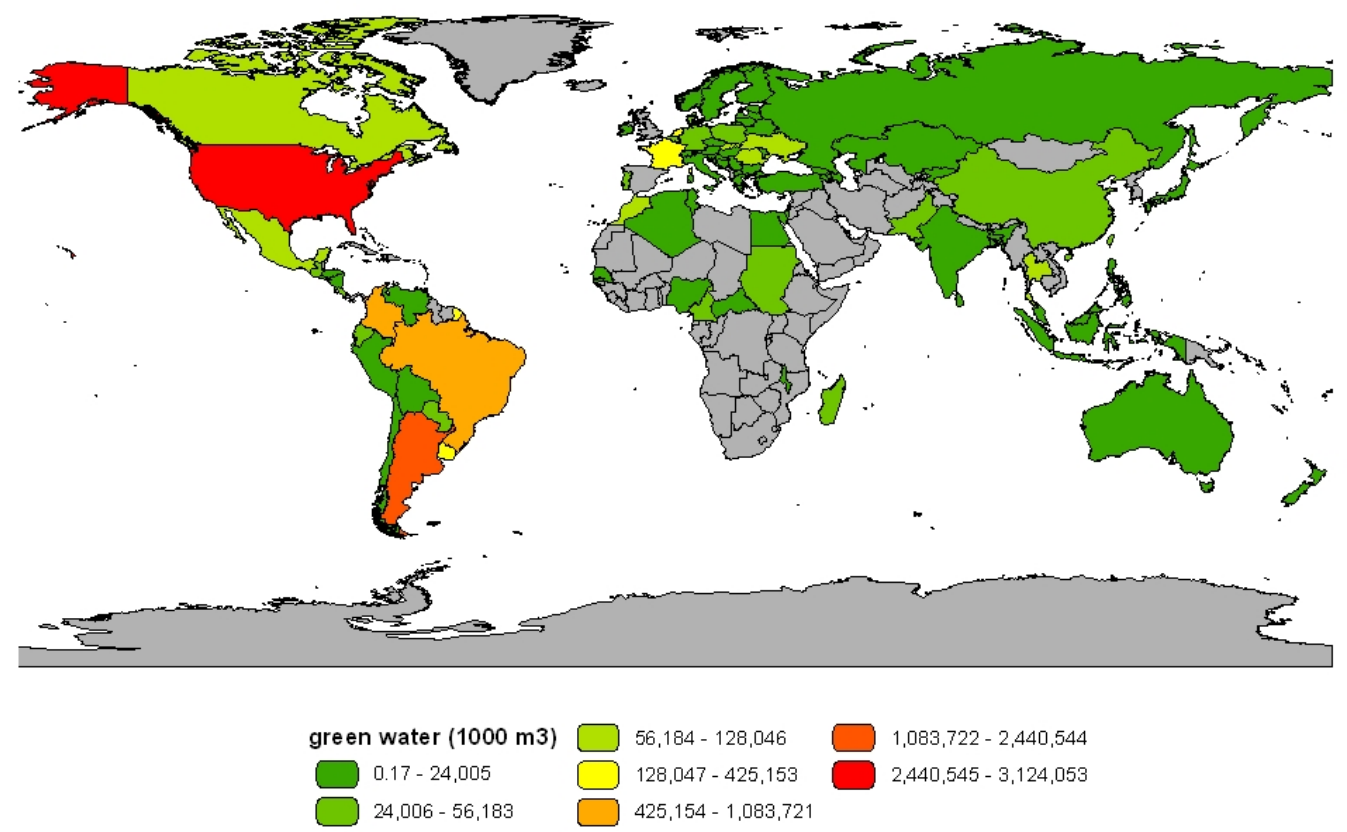



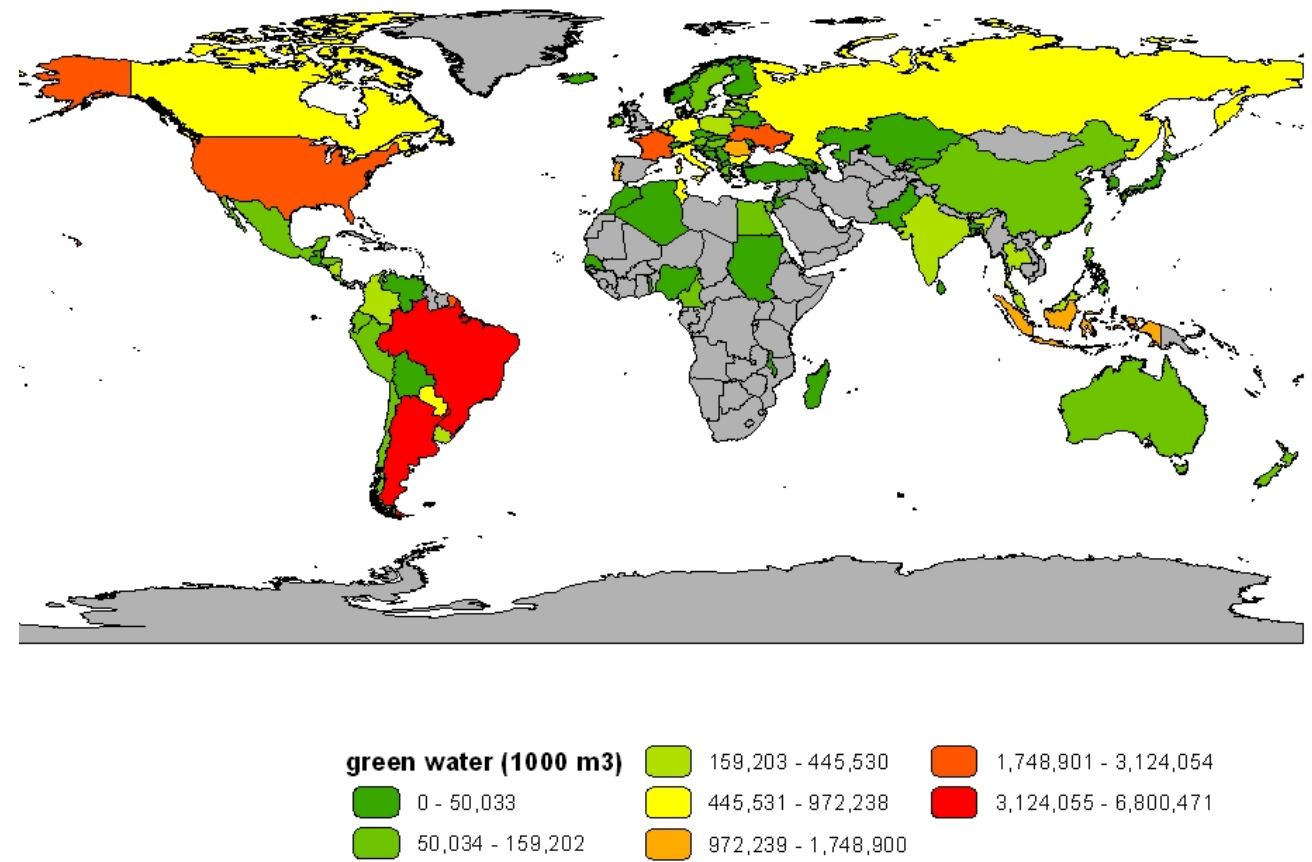

Figure SI4: Origin of blue water embodied in products imported by Spain, 1965(thousand $\mathrm{m}^{3}$ )

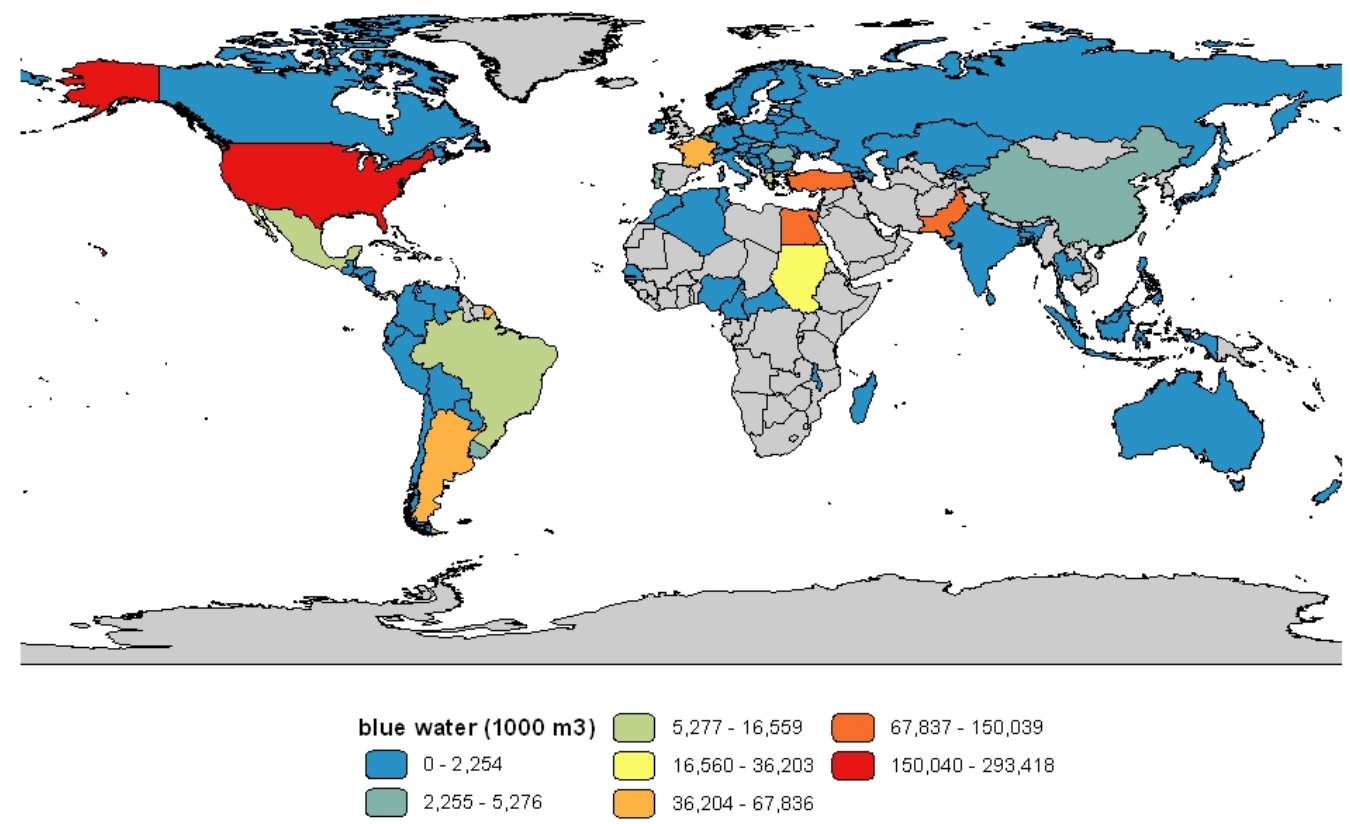


Figure SI5: Origin of blue water embodied in products imported by Spain, 2010(thousand $\mathrm{m}^{3}$ )

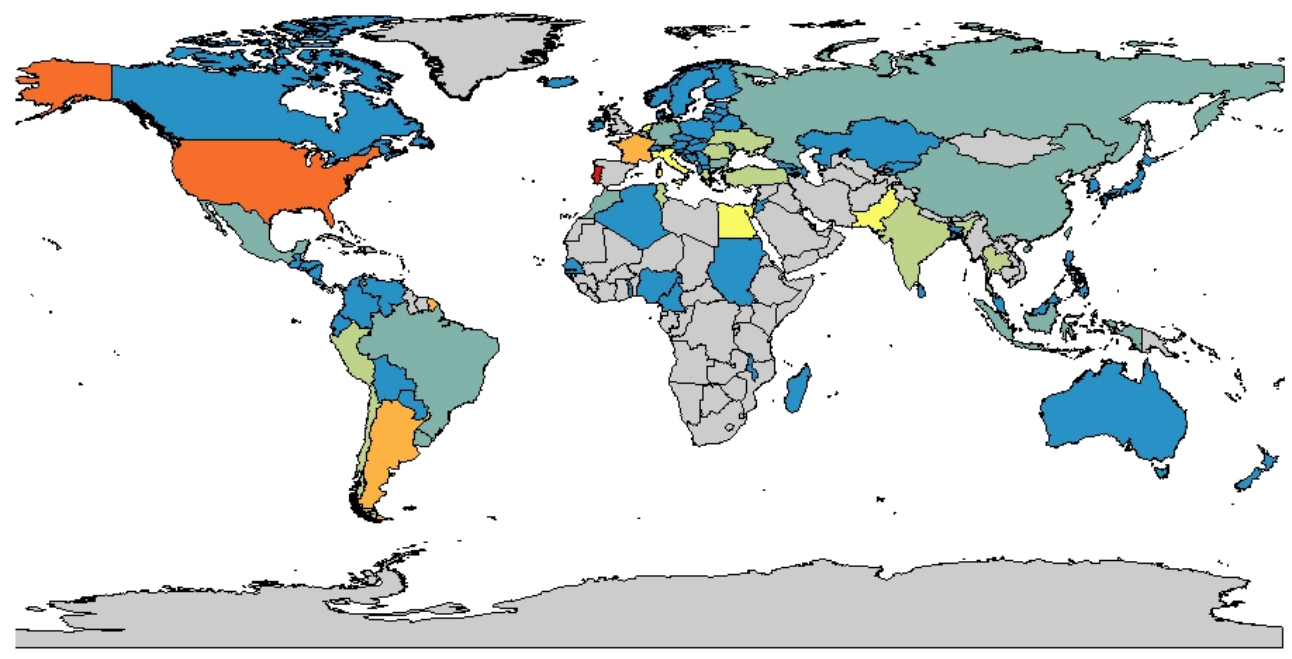

\begin{tabular}{|c|c|c|}
\hline blue water $(1000 \mathrm{~m} 3)$ & $16,577-44,024$ & $326,405-476,571$ \\
\hline $0-6,154$ & $44,025-102,929$ & $476,572-813,006$ \\
\hline $6,155-16,576$ & $102,930-326,404$ & \\
\hline
\end{tabular}




\section{Appendix 1: Uncertainty}

384 Water coefficients from Mekonnen and Hoekstra $(2011,2012)$ offer information on the average virtual water content for the years 1996-2005. As we explain in the text, these water intensities $\left(\mathrm{m}^{3} /\right.$ ton) are obtained as the ratio between water demand evapotranspiration (crop water use) and crop yields. Evapotranspiration under non-optimal conditions is dependent on climate, crop characteristics, and management and environmental conditions. While Allen et al., 1998 consider that crop parameters can be assumed to be static, Duarte et al. (2014b) show that real evapotranspiration could be considered stationary in the long term, providing confidence in the hypothesis of constant water evapotranspiration during the period studied.

Although it is feasible to assume constant evapotranspiration, the virtual water content of crops and livestock products cannot be considered static, given the significant improvements in technical and managerial water practices taking place from 1965 to 2010. Thus, as described in the text, water intensities $\left(\mathrm{m}^{3} /\right.$ ton) have been modified on the basis of yield series, following Equation 14 .

Equation 14 assumes a decreasing, convex with respect to the origin, and hyperbolic relationship. The function in equation 14 is a hyperbola that involves the virtual water content gradually declining as crop yield increases (see the blue line in figure SI6). This is an approach in which a dynamic, inverse, and nonlinear relationship between crop yields and virtual water content is assumed (of a crop or group of crops, on average, in a country). However, the function presented in Equation 14 has constant elasticity, which means that a percentage change in the crop yield involves a constant percentage change in the virtual water content. In other words, it is linear in logarithms, but not in levels. There are alternative methods to obtain variable data on the virtual water content of products, such as that proposed by Rockström (2003) and Rockström et al. (2007) for the case of cereals. On the basis of their approach, the water content of water can be related to crop yields following the relationship $\mathrm{WP}=\frac{\mathrm{WP}_{\mathrm{T}}}{\left(1-\mathrm{e}^{\mathrm{bY}}\right)}$, where $\mathrm{WP}$ is green water productivity (water intensity), $\mathrm{WP}_{\mathrm{T}}$ is green water productivity, $\mathrm{b}$ is a constant that determines the rate of decline in evaporation with increased crop canopy, and Y is the crop yield. Figure SI6 
412 (green line) shows that this function is also a decreasing, convex and hyperbolic function.

413 The main difference between these two methods is that, in the case of Rockström (2003)

414 and Rockström et al. (2007), the ratio between the crop yield and the water productivity

415 changes with the level of yield and there exists a horizontal asymptote for a specific level of 416 green water productivity $\mathrm{WP}_{\mathrm{T}}$.

417 Figure SI6: Behavior of equation 14 and of the formula proposed by Rockström

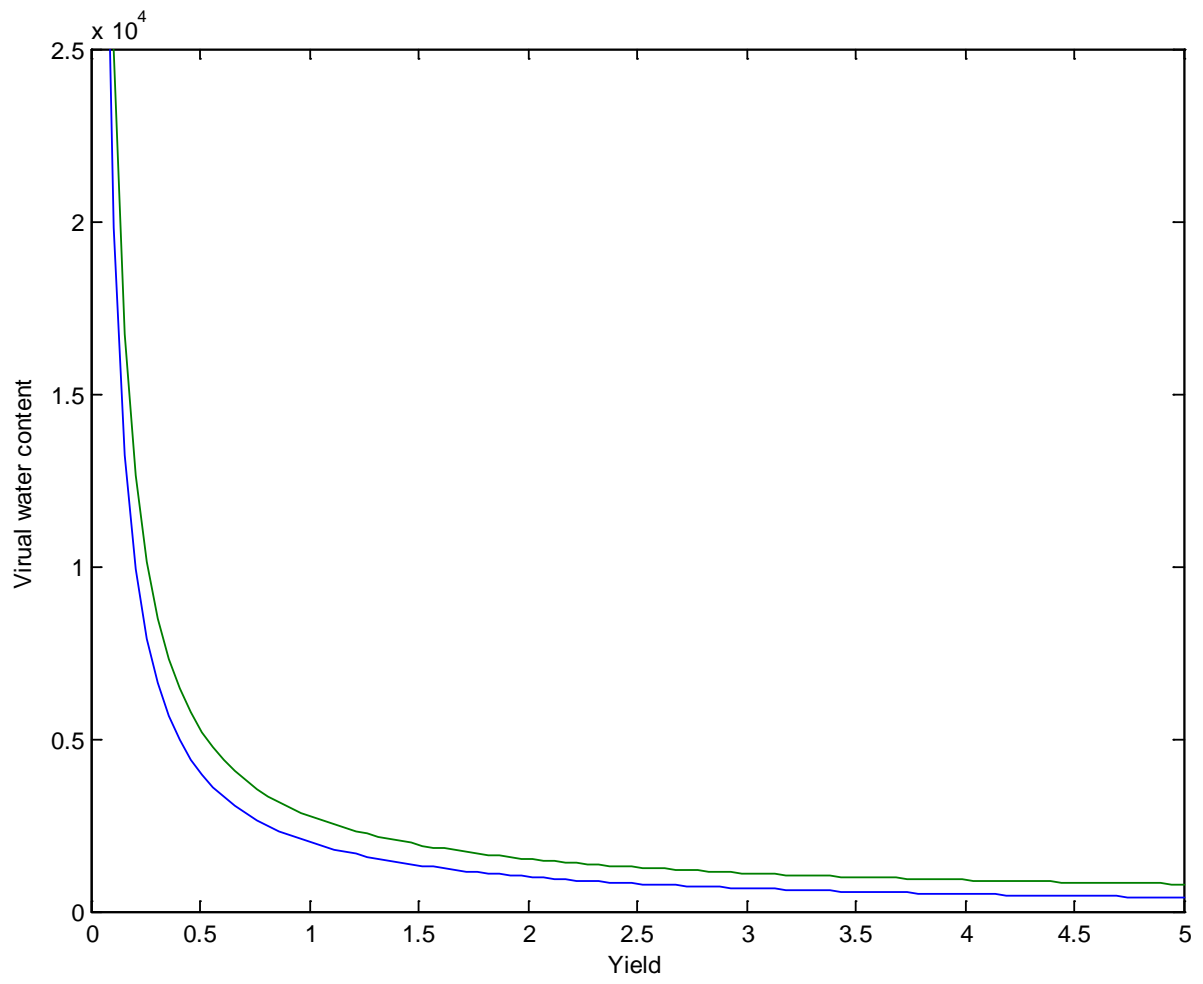

418

419

420

421

422

423

424

425

42

427

428

Figure obtained for the simulated values: $b=-0.2, W P T=500$ and $w_{c p}^{*} y c p=2000$

The idea of changing rates of decrease constitutes an interesting approach to this relationship but, as can be seen, the full behaviour of this curve depends on two parameters: the optimum level of productive green water (WPT) and the parameter driving the decreasing rate (b). While a formulation in this line could be carried out with precise information about the response rate of detailed crops in specific regions, additional assumptions about $\mathrm{b}$ and WPT would be necessary for all crops and countries with which Spain has been trading during more than 40 years. Clearly, this prevents the implementation of such an approach in our analysis. However, both approximations share important characteristics regarding the declining, and the hyperbolic functional form. 
429

430

431

432

433

434

435

436

437

438

439

440

441

442

\section{Figure SI7: Comparison of green water intensities for Millet (m3/tom) with constant coefficients from Hoekstra} (Black), variable coefficients as in Dalin et al. (2012) (red) and variable coefficients as in Rockström (green).

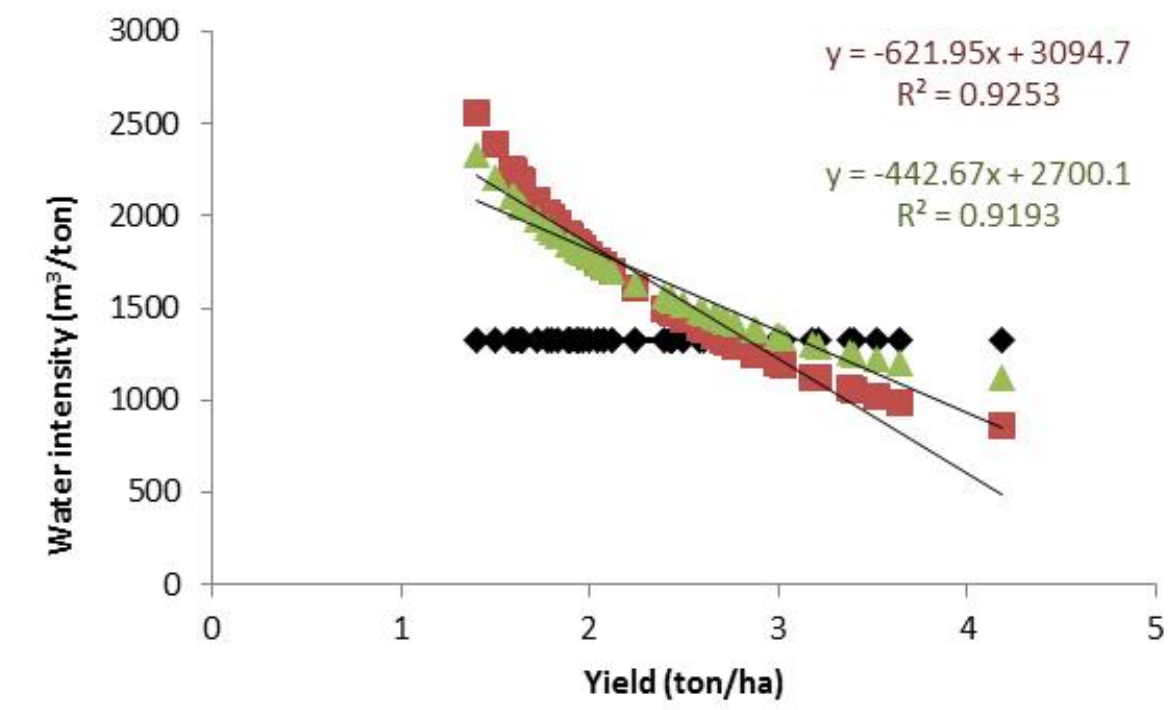

443

Additionally, in order to give an evaluation of the bias between both approaches, we have compared the results under the two alternative methods for green water consumption in the case of millet (one of the grains analysed in Rockström (2003)). Thus, we use the values $\mathrm{WP}_{\mathrm{T}}=800 \mathrm{~m}^{3} /$ ton and $\mathrm{b}=-0.3$ proposed in their paper.

The constant green water coefficient given by Mekonnen and Hoekstra (2011) for Millet $(1,321.7 \mathrm{~m} 3 /$ ton $)$ is represented by the black series. The relationship between the virtual green water content for millet and its yield, as proposed in our study, is shown in red, and the link between green virtual water content and the yield of millet as proposed by Rockström (2003) is displayed in green. As can be seen in figure SI7, the results seem to be quite similar for most yield levels, showing close $\mathrm{R}^{2}$ coefficients, higher than 0.9 . Although discrepancies of around $20 \%$ can be found only for the higher yield values, on average, the difference between these two estimates ranges from $5 \%$ to $8 \%$.

- fix coefficient $\mathbf{E}$ variable coefficient $\Delta$ variable coefficient rockstrom 